\title{
HUBUNGAN SPASIAL TRANSAKSI TANAH DENGAN PERKEMBANGAN WILAYAH DI KABUPATEN CIREBON, JAWA BARAT
}

\author{
Spatial Pattern Relationship between Land Transaction and Regional \\ Development in Cirebon Regency, West Java
}

\section{Amin Marzuki ${ }^{1}$, Santun R.P. Sitorus ${ }^{2}$ and Soekmana Soma ${ }^{3}$}

\begin{abstract}
Abstrak: Potensi besar Kabupaten Cirebon dengan akses transportasi dan bonus demografi penduduk dapat mendorong perkembangan wilayah. Faktanya, belum semua potensi optimal untuk mengundang investasi di Kabupaten Cirebon. Salah satu penyebabnya adalah sebagian besar lahan belum terdaftar, sehingga menghambat investasi yang memerlukan lahan. Kami mengeksplorasi hubungan secara spasial tingkat perkembangan wilayah dengan transaksi tanah. Kami menghitung indeks diversifikasi entropi untuk melihat tingkat perkembangan wilayah. Kami juga menginterpolasi transaksi tanah untuk melihat pola spasialnya. Metode interpolasi natural neighbor digunakan untuk melihat pola spasial transaksi tanah. Tumpang susun antara peta indeks entropi dengan peta pola transaksi tanah dilakukan untuk melihat hubungan secara spasial. Transaksi tanah di kabupaten Cirebon berkumpul di wilayah yang sangat berkembang dan berkembang. Kecamatan Palimanan, Depok, Plumbon, Weru dan Plered yang dikategorikan sangat berkembang memiliki jumlah transaksi dan nilai transaksi tanah lebih besar dibandingkan wilayah yang belum berkembang. Pasaleman yang memiliki indeks entropi paling kecil dan dikategorikan belum berkembang memiliki jumlah dan nilai transaksi tanah lebih rendah. Kami menemukan ada kesamaan pola spasial antara peta tingkat perkembangan wilayah dengan hasil interpolasi transaksi tanah.
\end{abstract}

Kata kunci: indeks entropi, interpolasi natural neighbor, perkembangan wilayah, transaksi tanah

\begin{abstract}
The big potential of Cirebon Regency with a good transportation access and demography bonus are able to promote its regional development. In fact, not all of the potential has been optimalized to invite investment in Cirebon Regency. One of the causes is some of the land haven't been registered, so that obstruct investment that requires land. We explore the spatial relationship between regional development level and land transaction pattern. We calculate the entropy diversification index to see the level of regional development. We also interpolate the land transaction to see the spatial pattern. The natural neighbor interpolation method was used to show spatial patterns of land transactions. Then, we overlay the map of entropy index and land transaction pattern map to see the relationship spatially. Land transactions in Cirebon Regency gathered in a very developed and developing region. Districts of Palimanan, Depok, Plumbon, Weru and Plered that are categorized very developed have more quantity of transactions and land transaction value than the undeveloped area. Pasaleman district has Kecamatan Depok has the
\end{abstract}

\footnotetext{
${ }^{1}$ Program Studi Ilmu Perencanaan Wilayah, Sekolah Pascasarjana IPB

${ }^{2}$ Departemen Ilmu Tanah dan Sumberdaya Lahan, Fakultas Pertanian IPB

${ }^{3}$ Departemen Ilmu Tanah dan Sumberdaya Lahan, Fakultas Pertanian IPB
} 
smallest entropy index and categorized as undeveloped has lower number and value of land transactions. We found a similar spatial pattern between the regional level of development and land transactions interpolation.

Keywords: entropy index, land transaction, natural neighbor interpolation, regional development.

\section{PENDAHULUAN}

Potensi wilayah Kabupaten Cirebon yang termasuk dalam tiga wilayah di Jawa Barat dengan fungsi sebagai Pusat Kegiatan Nasional (PKN) selain Bandung Raya dan Bodebekapur (Bogor, Depok, Karawang dan Bekasi). Pemerintah daerah disana bersepakat untuk memproyeksikan Ciayumajakuning (istilah untuk PKN Cirebon, Indramayu, Majalengka dan Kabupaten Kuningan) tahun 2028 sebagai pusat pertumbuhan ekonomi yang prestisius. Sesuai dengan Konsep PKN Ciayumajakuning, Kabupaten Cirebon diharapkan menjadi pilar yang memicu perkembangan wilayah disekitarnya. Faktanya sesuai dengan data PDRB Kabupaten/Kota disekitarnya, laju pertumbuhan ekonomi Kabupaten Cirebon hampir seluruhnya dibawah Propinsi Jawa Barat dan wilayah sekitar. Dari sisi transportasi, Kabupaten Cirebon memiliki akses yang cukup lengkap, mulai dari jalan nasional pantura, Jalan Tol Cipali-Palikanci, jalur kereta api, Pelabuhan hingga Bandara Internasional Jawa Barat (BIJB) Kertajati yang menjadi bagian dari Ciayumajakuning.

Hal ini merupakan potensi pengembangan Kabupaten Cirebon untuk menarik investor ke wilayah ini, sehingga perlu didukung dengan indeks kemudahan dalam melakukan usaha (ease of doing business) yang baik dengan beberapa indikator diantaranya adalah perbaikan memulai berbisnis, akses mendapatkan listrik, pendaftaran aset lahan. Indeks kemudahan berbisnis Indonesia yang dirilis oleh bank dunia, menempatkan Indonesia pada peringkat 109 dengan indeks pendaftaran tanah 131 dari 189 negara (The World Bank, 2016). Hal ini menunjukan bahwa salah satu penghambat dalam kemudahan berbisnis di Indonesia saat ini adalah pendaftaran tanah.

Data pertanahan digital di Kabupaten Cirebon hingga Agustus 2017, persentase tanah terdaftar dibandingkan dengan luas wilayah non kawasan hutan adalah kurang dari $30 \%$ dengan luas rata-rata tanah adalah 1,034 meter. Artinya sekitar 654 ribu bidang tanah di kabupaten cirebon belum mempunyai sertipikat hak atas tanah. Selain itu dalam 10 hingga 15 tahun kedepan Kabupaten Cirebon akan mengalami bonus demografi penduduk. Data Badan Pusat Statistik menyebutkan penduduk usia 10-60 tahun sebesar 76\% dan $24 \%$ adalah usia 0 hingga 9 dan lebih dari 60 tahun(Badan Pusat Statistik, 2016). Untuk menyambut bonus demografi, iklim investasi yang baik dan kemudahan dalam berusaha perlu diperbaiki untuk kesejahteraan masyarakat.

Perkembangan wilayah sebagai salah satu wujudnya adalah aktifitas ekonomi yang makin berkembang dan komposisinya makin berimbang (Rustiadi et al., 2017). Peningkatan aktifitas ekonomi erat kaitanya dengan investasi sehingga selain mewujudkan wilayah yang berkembang juga pertumbuhan ekonomi. Menurut The World Bank (2017) indeks kemudahan berbisnis Indonesia adalah 109 dari 189 negara dengan indeks registering property yaitu 131. Hal ini menempatkan indeks kemudahan berbisnis Indonesia pada urutan 91 dengan indeks registering property adalah 118 dari 190 negara. Hal ini memperlihatkan bahwa pendaftaran hak atas tanah menjadi salah satu faktor penting dalam menumbuhkan iklim investasi disuatu wilayah. Dengan bahasa yang lain, property right yang jelas akan berpengaruh positif dengan tingkat pembangunan ekonomi, akses kredit dan pembentukan modal (Williamson, 2010). Semakin aman hak atas tanah di suatu wilayah maka semakin tinggi tingkat investasi (Johnson et al., 2002). Senada dengan Reerink \& van Gelder (2010), Keamanan atas kepemilikan lahan, menyebabkan mereka bersedia berinvestasi. 
Aktifitas ekonomi dan kesejahteraan masyarakat yang meningkat biasanya akan berkorelasi dengan alih fungsi lahan pertanian untuk tempat usaha, karena populasi yang lebih besar di tempat yang lebih berkembang (Dow et al., 2017). Peningkatan populasi akan menyebabkan perkembangan ekonomi yang memerlukan alokasi lahan untuk industri, infrastruktur dan jasa (Munibah et al., 2009) selalu diiringi meningkatnya peningkatan kebutuhan ketersediaan fasilitas (Sitorus et al., 2012) serta akan meningkatkan permintaan lahan yang sebagian besar untuk perumahan dan kawasan industri (Winarso \& Firman, 2002). Semakin banyak transaksi tanah mengindikasikan permintaan tanah juga tinggi. Transaksi tanah merupakan salah satu aktifitas ekonomi yang tercatat perpindahan kepemilikannya. Prinsip ekonomi menyebutkan bahwa semakin tinggi permintaan terhadap barang maka semakin tinggi harga barang tersebut, tidak terkecuali tanah.

Tujuan penelitian ini adalah: 1) mengetahui tingkat perkembangan wilayah tiap kecamatan di Kabupaten Cirebon; 2) mengetahui hubungan spasial antara tingkat perkembangan wilayah dengan transaksi tanah di Kabupaten Cirebon.

\section{METODE}

\section{Lokasi dan Waktu Penelitian}

Penelitian ini dilakukan Kabupaten Cirebon, Provinsi Jawa Barat. Kabupaten Cirebon terdiri dari empat puluh kecamatan terletak antara 108020'00" - 108050'20" Bujur Timur dan 06030'30" - 07000'00" Lintang Selatan. Pelaksanaan penelitian ini adalah bulan Agustus 2017.

\section{Jenis dan sumber data}

Jenis data yang digunakan dalam penelitian ini adalah data sekunder yang dikumpulkan dari berbagai sumber data. Data transaksi tanah 2014-2017 diperoleh dari Pusat Data dan Informasi, Kementerian Agraria dan Tata Ruang/ Badan Pertanahan Nasional. Data PDRB (Produk Domestik Regional Bruto) menurut lapangan usaha Kabupaten Cirebon per kecamatan tahun 2010 dan 2015 yang merupakan data paling baru berdasarkan laporan BPS.

\section{Analisis Data}

\section{Analisis Tingkat Perkembangan Wilayah}

Perkembangan wilayah dapat ditunjukkan dari semakin meningkatnya komponen wilayah, misalnya alternatif sumber pendapatan wilayah dan aktifitas perekonomian di wilayah tersebut, semakin luasnya hubungan yang dapat dijalin antara subwilayahsubwilayah dalam sistem tersebut maupun dengan sistem sekitarnya. Perluasan jumlah komponen aktifitas ini dapat dianalisis dengan menghitung indeks diversifikasi dengan konsep entrophy (Panuju \& Rustiadi, 2012)

Indeks Entropi memperlihatkan bahwa semakin beragam aktifitas atau semakin luas jangkauan spasial, maka semakin tinggi Entropi wilayah. Artinya wilayah tersebut semakin berkembang. Semakin tinggi entropi semakin berkembang suatu sistem. Entropi selalu lebih besar dari 0 dengan pola hubungan antara peluang komponen dengan nilai entropinya berbentuk kurva kuadratik dengan nilai maksimum $1 / \mathrm{n}$. Hal ini menunjukan entropi akan maksimum pada saat peluang di seluruh komponen sama dengan $1 / \mathrm{n}$. Nilai entropi maksimumnya adalah sebesar $\ln (n)$. Persamaan umum Entropi adalah sebagai $\stackrel{\text { berikut }}{=} P_{i} \ln (P i)$ 
Pi adalah peluang yang dihitung dari persamaan $x i / \sum X$ dan $\sum P i=1$

$\mathrm{x} 1 \mathrm{x} 2 \mathrm{x} 3 \mathrm{x} 4=\mathrm{X}$

$\mathrm{x} 1 / \mathrm{X} \quad \mathrm{x} 1 / \mathrm{X}=1$

Jika matrix terdiri dari baris dan kolom yang cukup banyak, maka persamaan untuk menghitung peluang titik pada kolom ke-i dan baris kej adalah:

Pij=xij/Xij, dimana: i = 1, 2, ...p; j = 1, 2, ...q; Pij = Peluang titik satu

kecamatan; $x i j=$ nilai PDRB Satu kecamatan; Xij = nilai PDRB Total Kabupaten Cirebon.

Identifikasi tingkat perkembangan sistem dengan konsep entropi ini berlaku bahwa semakin tinggi nilai entropi maka tingkat perkembangan suatu sistem akan semakin tinggi. Nilai entropi selalu lebih besar atau paling tidak sama dengan $0(S \geq 0)$. Nilai maksimum entropi diperoleh pada saat nilai peluangnya sama dengan $1 / \mathrm{n}$, dimana $\mathrm{n}$ adalah jumlah seluruh titik (sektor/komponen/jangkauan spasial). Nilai entropi maksimum tersebut akan sama dengan $\ln (\mathrm{n})$. Nilai $\ln (\mathrm{n})$ maksimum terjadi dalam kondisi seluruh lokasi dan atau aktifitas memiliki nilai sama. Dengan demikian, dapat diartikan bahwa seluruh aktifitas berkembang dengan peluang perkembangan yang sama. Sementara itu nilai minimum sama dengan 0 yang terjadi pada saat seluruh aktifitas dan atau seluruh lokasi sama dengan 0 .

Data yang digunakan untuk menghitung indeks perkembangan wilayah terlebih dahulu dilakukan analisis entropi. Selanjutnya, hasil indeks diversifikasi entropi digunakan untuk melakukan klasifikasi tingkat perkembangan wilayah. Klasifikasi tingkat perkembangan wilayah dilakukan dengan membagi tiga kategori yaitu sangat berkembang, berkembang dan belum berkembang. Klasifikasi ini menggunakan metode natural breaks. Penelitian ini menggunakan peta dengan sistem koordinat geografis dan Datum WGS-84. Tahapan yang telah dilakukan untuk mendapatkan peta tingkat perkembangan wilayah adalah : 1) Penyiapan data batas wilayah berdasarkan data BAPPEDA Kabupaten Cirebon menggunakan perangkat lunak ArcGIS 10; 2) Penyiapan data PDRB per Kecamatan menggunakan perangkat lunak Microsoft Excel; 3) Perhitungan indeks diversifikasi entropi menggunakan perangkat lunak Microsoft Excel; 4) Klasifikasi serta penyajian tingkat perkembangan wilayah menggunakan perangkat lunak ArcGIS 10.

\section{Analisis Pola Transaksi Tanah}

Pola transaksi jual beli dan agunan tanah secara spasial dapat dilakukan dengan metode interpolasi baik berdasarkan jumlah transaksi maupun nilai transaksi. Hal ini dimaksudkan untuk mengetahui pada wilayah mana terjadi transaksi yang tinggi dan sebaliknya. Proses interpolasi adalah mengisi kekosongan data dengan metoda tertentu dari suatu kumpulan data untuk menghasilkan sebaran yang kontinyu. Pada modul Spatial Analyst yang di miliki oleh perangkat lunak ArcGIS, proses ini dilakukan dengan menjalankan fungsi Interpolate Grid yang terdapat pada menu Surface. Ada beberapa metode yang bisa digunakan untuk melakukan interpolasi seperti Spline, Inverse Distance Weighted (IDW), Kriging dan Natural Neighbour. Setiap metode ini akan memberikan hasil interpolasi yang berbeda.

Metode IDW dapat dikelompokkan dalam estimasi deterministik dimana interpolasi dilakukan berdasarkan perhitungan matematik. Sedang metode kriging dapat digolongkan kedalam estimasi stochastic dimana perhitungan secara statistik dilakukan untuk menghasilkan interpolasi. Menurut Pramono (2008) untuk mendapatkan hasil yang baik pada interpolasi IDW, sampel data yang digunakan harus rapat yang berhubungan dengan variasi lokal. Jika sampelnya agak jarang dan tidak merata, hasilnya kemungkinan besar tidak sesuai dengan yang diinginkan. etode Kriging diketemukan oleh D.L. Krige dimana menggunakan kombinasi linear dari bobot untuk memperkirakan nilai diantara sampel data 
(Pramono, 2008). Metode ini menggunakan semivariogram yang merepresentasikan perbedaan spasial dan nilai diantara semua pasangan sampel data. Semivariogram juga menunjukkan bobot (weight) yang digunakan dalam interpolasi. Berbeda dengan Kriging dan IDW, Natural Neighbor adalah metode interpolasi yang dikembangkan oleh Robin Sibson. Metode ini memiliki kelebihan yaitu lebih sederhana dan aproksimasi lebih halus. Gambar 1. merupakan ilustrasi dari interpolasi natural neighbor.

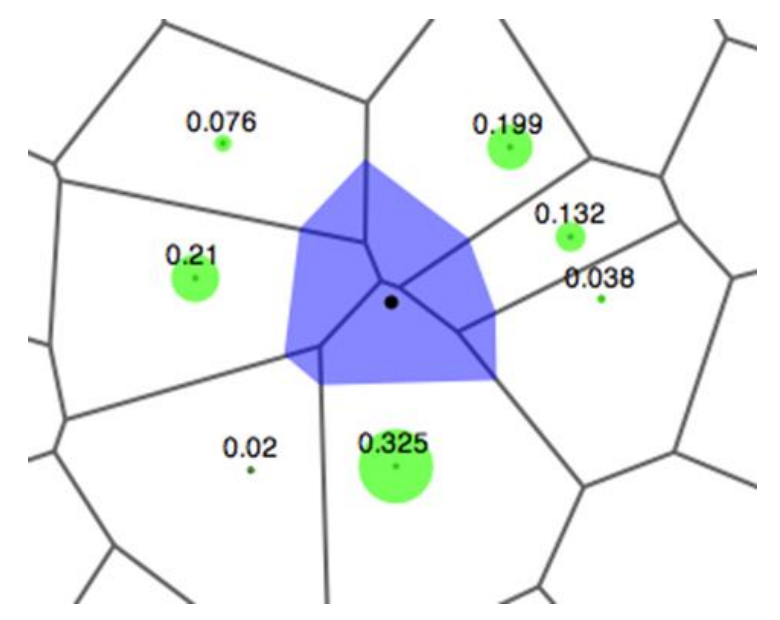

Gambar 1. Ilustrasi Natural Neighbor Interpolation

Persamaan dasar interpolasi natural neighbor adalah sebagai berikut:

$G(x, y)=\sum_{i=1}^{n} w_{i} f\left(x_{i} y_{i}\right)$

Dimana $\boldsymbol{G}(\boldsymbol{x}, \boldsymbol{y})$ adalah nilai estimasi $(\boldsymbol{x}, \boldsymbol{y}), \boldsymbol{w}_{\boldsymbol{i}}$ adalah pembobotan dan $\boldsymbol{f}\left(\boldsymbol{x}_{\boldsymbol{i}} \boldsymbol{y}_{\boldsymbol{i}}\right)$ adalah data yang diketahui.

Lingkup analisis dilakukan terhadap data sebaran transaksi tanah. Data transaksi tanah merupakan data jual beli tanah yang dicatat dalam akta jual beli tanah di Kantor Pertanahan Kabupaten Cirebon. Definisi tanah digunakan dilingkup pemerintahan, terutama di Kementerian Agraria dan Tata Ruang/ Badan Pertanahan Nasional (ATR/BPN) yang mengacu pada lahan. Data transaksi tanah yang digunakan adalah data mulai 1-juli 2014 sampai dengan 30 juni 2017. Tahapan yang telah dilakukan untuk mendapatkan peta pola transaksi tanah adalah: 1) Penyiapan data sebaran transaksi tanah di Kabupaten Cirebon menggunakan perangkat lunak ArcGIS 10; 2) Interpolasi dengan menggunakan ArcGIS 10; 3) Klasifikasi hasil interpolasi menggunakan ArcGIS 10 dengan metode Natural Breaks; 4) Penyajian peta hasil interpolasi menggunakan perangkat lunak ArcGIS 10.

\section{HASIL DAN PEMBAHASAN}

\section{Hasil Analisis Tingkat Perkembangan Wilayah}

Pelaksanaan pembangunan merupakan wujud dari usaha pemerintah dalam mencapai tujuan yaitu kesejahteraan masyarakat. Perkembangan wilayah adalah salah satu aspek yang sebaiknya juga dipertimbangkan dalam pembangunan. Hal ini selain untuk meminimalisir kesenjangan pembangunan antar wilayah juga digunakan untuk memicu perkembangan wilayah sekitarnya. Kesenjangan pembangunan terjadi jika penyebaran 
pembangunan hanya terpusat pada wilayah tertentu. Perkembangan wilayah bisa didekati dengan analisis pencapaian hasil pembangunan melalui indikator-indikator kinerja di bidang ekonomi dan sosial serta bidang-bidang lain, salah satunya dengan menggunakan analisis indeks entropi.

Perkembangan aktivitas ekonomi pada suatu wilayah dapat didekati dengan menghitung indeks diversifikasi dengan konsep entropi. Indeks entropi mempunyai prinsip bahwa semakin beragam aktivitas atau semakin luas jangkauan spasial, maka semakin tinggi entropi wilayah, artinya wilayah tersebut semakin berkembang. Aktivitas ekonomi wilayah bisa dicerminkan dari perkembangan sektor-sektor perekonomian dalam PDRB. Selain itu, semakin besar indeks entropi juga semakin proporsional komposisi antar sektorsektor perekonomiannya. Sebaliknya, semakin kecil indeks maka bisa diasumsikan terdapat sektor perekonomian yang dominan di wilayah tersebut. Hasil perhitungan indeks entropi kecamatan dan sektor-sektor perekonomiannya di Kabupaten Cirebon 2015 tertera pada Tabel 1 dan Gambar 2

Tabel 1. Hasil Analisis Indeks Entropi Wilayah Tahun 2015

\begin{tabular}{llllll}
\hline NO & KECAMATAN & INDEKS & NO & KECAMATAN & INDEKS \\
\hline 1 & PASALEMAN & 0.0641 & 21 & LEMAHABANG & 0.1356 \\
2 & GREGED & 0.0768 & 22 & MUNDU & 0.1363 \\
3 & WALED & 0.0844 & 23 & KEDAWUNG & 0.1386 \\
4 & KARANGSEMBUNG & 0.0874 & 24 & GEBANG & 0.1389 \\
5 & KARANGWARENG & 0.0886 & 25 & SUSUKAN & 0.1403 \\
6 & BEBER & 0.0896 & 26 & KAPETAKAN & 0.1417 \\
7 & PABEDILAN & 0.0965 & 27 & TALUN & 0.1431 \\
8 & GEMPOL & 0.0973 & 28 & CILEDUG & 0.1462 \\
9 & SUSUKAN LEBAK & 0.0986 & 29 & PANGURAGAN & 0.1469 \\
10 & JAMBLANG & 0.0988 & 30 & SUMBER & 0.1495 \\
11 & SEDONG & 0.1006 & 31 & DUKUPUNTANG & 0.1569 \\
12 & CIWARINGIN & 0.1068 & 32 & GEGESIK & 0.1603 \\
13 & KALIWEDI & 0.1105 & 33 & GUNUNGJATI & 0.1659 \\
14 & PABUARAN & 0.1175 & 34 & ARJAWINANGUN & 0.1859 \\
15 & KLANGENAN & 0.1181 & 35 & ASTANAJAPURA & 0.2110 \\
16 & SURANENGGALA & 0.1192 & 36 & WERU & 0.2301 \\
17 & PANGENAN & 0.1201 & 37 & DEPOK & 0.2310 \\
18 & BABAKAN & 0.1335 & 38 & PLERED & 0.2373 \\
19 & LOSARI & 0.1337 & 39 & PLUMBON & 0.2601 \\
20 & TENGAH TANI & 0.1353 & 40 & PALIMANAN & 0.2931 \\
\hline
\end{tabular}

Tabel 1 memperlihatkan bahwa indeks entropi kecamatan-kecamatan di Kabupaten Cirebon tahun 2015 dengan nilai diatas rata-rata nilai indeks $(0,1407)$ hanya berjumlah 15 kecamatan dari 40 Kecamatan atau 37\% dari jumlah kecamatan. Hal ini menunjukkan, secara umum perkembangan proporsi keragaman sektor perekonomian di Kabupaten Cirebon belum cukup baik. Kecamatan Palimanan mempunyai indeks entropi yang paling tinggi tahun 2015 dengan nilai 0,2931 dan berada diatas rata-rata nilai indeks $(0,1407)$, tahun 2010 dengan nilai 0,3007 diatas rata-rata nilai indeks $(0,1387)$. Hal ini dipengaruhi oleh nilai PDRB Kecamatan Palimanan yang menduduki peringkat paling tinggi. Ini mengindikasikan bahwa Kecamatan Palimanan merupakan wilayah yang paling berimbang dan terdiversifikasi perkembangan sektor-sektor perekonomian dengan baik sehingga tidak didominasi oleh sektor tertentu saja. Kecamatan Palimanan dan Plumbon sesuai dengan Rencana Pemerintah Jangka Menengah Daerah (RPJMD) hingga 2019, diproyeksikan menjadi Pusat Kegiatan Lokal (PKL) dengan fungsi utama sebagai sentra industri. Fungsi lainnya adalah kawasan perdagangan, pertambangan, pertanian hingga penunjang Pusat Kegiatan Nasional (PKN). 
Bentuk keseriusan dari rencana pemerintah diwilayah PKL Plumbon Palimanan ini terlihat dari berkembangnya industri, perdagangan dan jasa diwilayah ini. Hal ini terlihat dari beberapa industri skala nasional seperti pabrik semen PT. Indocement dan PT. Samator Gas Industri berdiri di PKL ini. Bagian belakang pabrik Indocement Palimanan ada gunung kapur yang bernama gunung kromong (gunung kapur) yang akan menjadi bahan baku semen. Gunung kapur ini juga masuk kawasan pabrik Indocement Palimanan, Cirebon. Bukan hanya industri, sektor pertambangan pun bergeliat tumbuh beriringan. Banyak warga yang juga menggantungkan hidup mereka dari keberadaan pabrik ini dan membantu tersedianya lapangan kerja. Bahkan wilayah ini pun memiliki fasilitas yang relatif lengkap seperti beberapa rumah sakit, hotel, restoran serta tempat perbelanjaan yang mendorong tersebarnya aktifitas perekonomian disana.

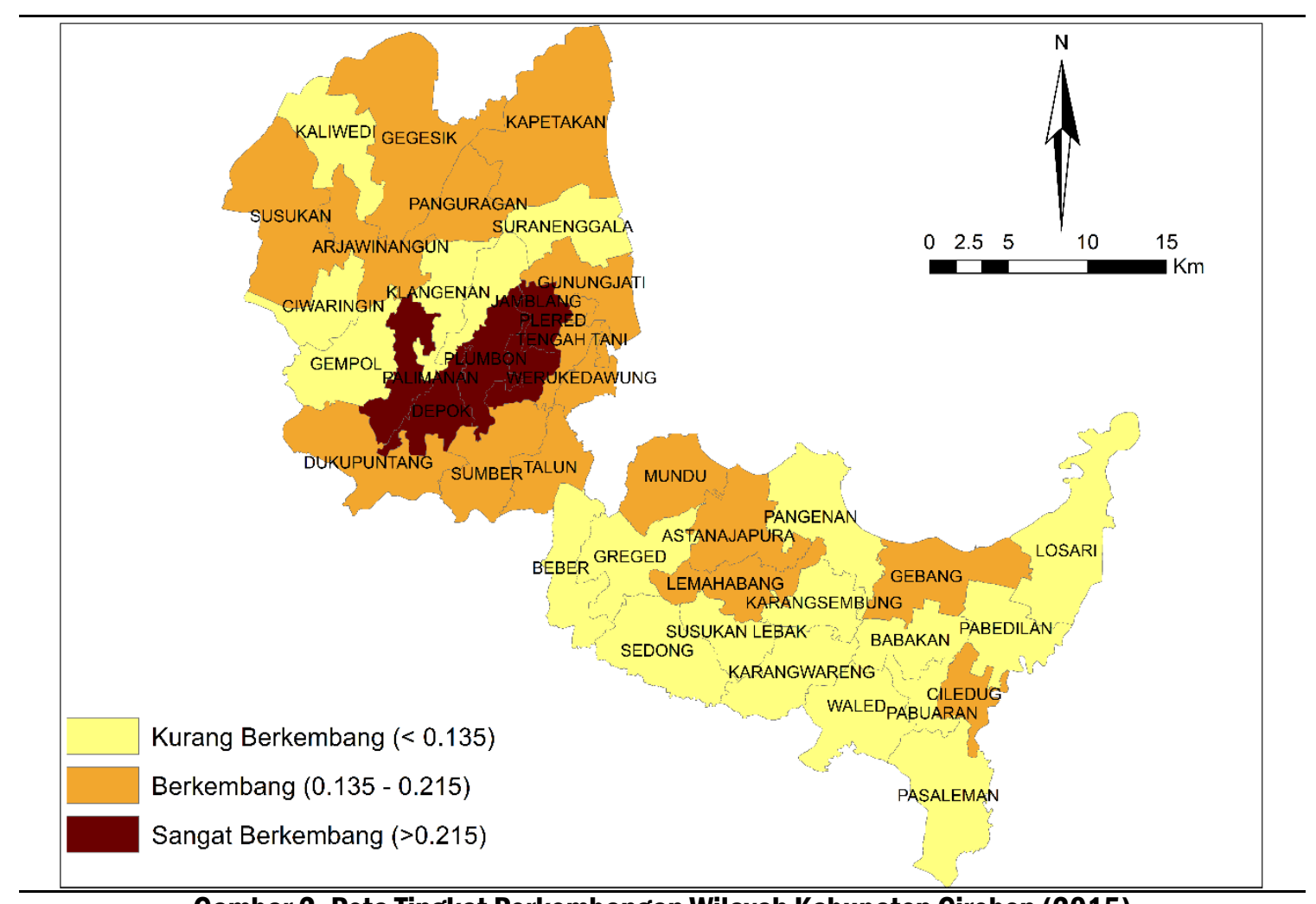

Gambar 2. Peta Tingkat Perkembangan Wilayah Kabupaten Cirebon (2015)

Sebaliknya Kecamatan Pasaleman mempunyai indeks entropi yang paling rendah tahun 2015 dengan nilai 0,064 dan berada di bawah rata-rata nilai indeks $(0,1407)$, tahun 2010 dengan nilai 0,053 dipengaruhi oleh nilai PDRB Kecamatan Pasaleman pun peringkat paling rendah. Wilayah ini secara geografis berada ujung timur Kabupaten Cirebon berbatasan dengan Propinsi Jawa Tengah dan Bagian Selatan berbatasan dengan Kabupaten Kuningan. Topografi Kecamatan ini berbukit dengan hampir sebagiannya adalah kawasan hutan. Hal ini dianggap menjadi salah satu pendorong aktifitas ekonomi belum terdiversifikasi secara merata di Kecamatan ini. RPJMD Kabupaten Cirebon merencanakan PKL dan PKLp (Pusat Kegiatan Lokal Promosi) Ciledug dan Losari dengan fungsi utama adalah kawasan pertanian dengan salah satu bagiannya adalah Kecamatan Pasaleman.

Berdasarkan analisis entropi perkembangan wilayah (Stot/Smaks), dapat diketahui bahwa nilai entropi Kabupaten Cirebon memiliki tingkat perkembangan sebesar 0,863 atau $86 \%$ dari kemampuan maksimumnya. Hal ini sedikit meningkat dibandingkan tahun 2010 
yaitu 0,851 atau 85\% dari target maksimumnya yang tetap yaitu 6,522. Gambar 9 adalah grafik perbandingan indeks entropi 2010 dan 2015 tiap kecamatan di Kabupaten Cirebon.

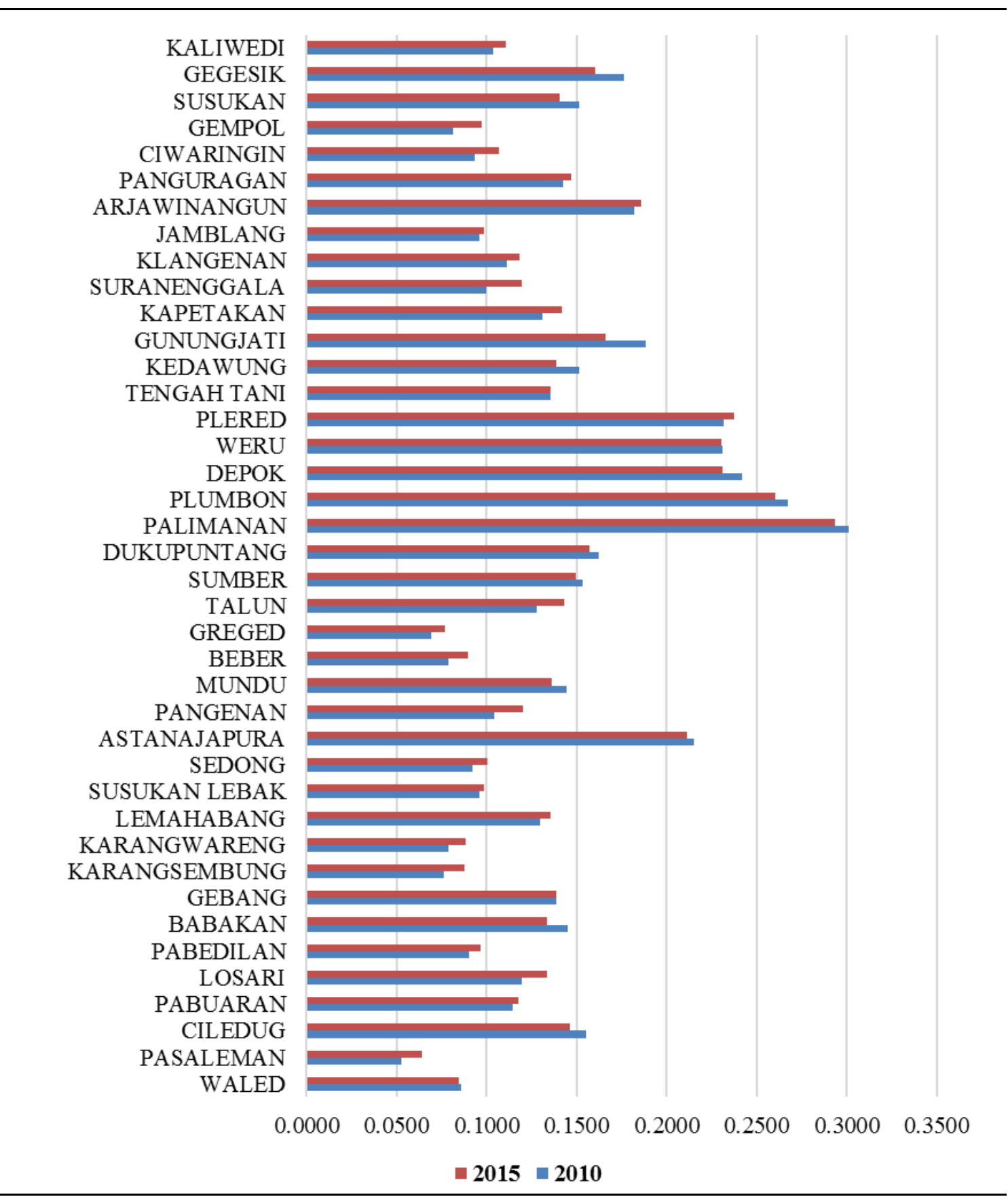

Gambar 3. Grafik Perbandingan Indeks Entropi 2010 dan 2015

Gambar 2 terlihat bahwa wilayah yang sangat berkembang adalah Palimanan, Plumbon, Depok, Weru dan Plered dengan pola yang mengumpul atau bertetangga. Hal serupa juga terlihat wilayah disekitarnya. Gambar 3 memperlihatkan bahwa beberapa wilayah bergeser dari sangat berkembang seperti Kecamatan Astanajapura menjadi berkembang. Sebaliknya lemahabang sebelumnya kurang berkembang menjadi berkembang. Hal ini diperkirakan karena ada pergeseran dari astanajapuran dan babakan 
yang merupakan tetangga di Kabupaten Cirebon bagian Timur. Pola yang tetap baik tahun 2010 maupun 2015 diperlihatkan oleh Kabupaten Cirebon bagian Barat. Gambar 4 merupakan peta tingkat perkembangan wilayah 2010. Hal ini menunjukan bahwa tingkat perkembangan wilayah di Kabupaten Cirebon relatif tetap dari tahun 2010 dan 2015.

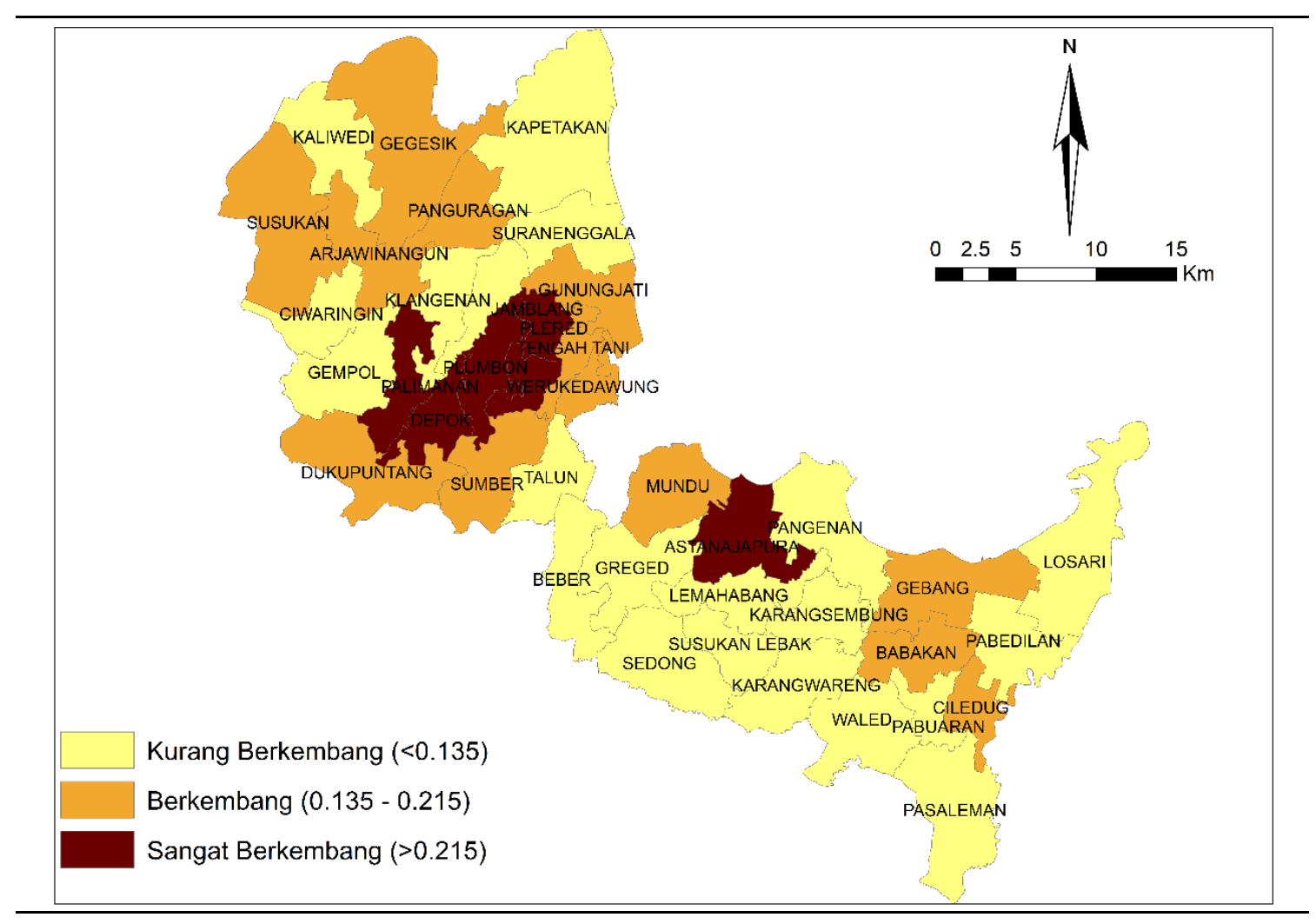

Gambar 4. Peta Tingkat Perkembangan Wilayah Kabupaten Cirebon (2010)

\section{Hasil Analisis Pola Transaksi Tanah}

Lahan mempunyai arti penting baik untuk hunian tempat tinggal maupun tempat melakukan aktifitas usaha dalam pemenuhan kebutuhannya. Peningkatan permintaan lahan bisa disebabkan oleh pertumbuhan jumlah penduduk, baik alamiah maupun urbanisasi. Tingginya permintaan lahan menyebabkan nilai lahan tumbuh mengikuti teori ekonomi dimana permintaan meningkat maka harga akan meningkat mengikuti permintaan, tidak terkecuali lahan. Sejalan dengan Wei, Kepemilikan lahan dan rumah yang besar merupakan bagian dari status ekonomi (Wei, Zhang, \& Liu, 2017) sertipikat hak atas tanah digunakan oleh usaha kecil dan menengah untuk mengembangkan usaha (Istikomah, 2013).

Analisis pola sebaran transaksi lahan dilakukan untuk wilayah mana yang sering terjadi jual beli lahan dan berapa kisaran harganya. Kemudian apakah wilayah tersebut secara spasial berkaitan dengan perkembangan wilayah. Pusat aktivitas ekonomi memiliki daya tarik kuat bagi masyarakat untuk memperoleh manfaat keterkaitan baik ke depan (forward linkage) maupun ke belakang (backward linkage) (Rustiadi et al., 2009). Hal ini memungkinkan wilayah yang mempunyai perkembangan lebih baik akan mempunyai harga lahan lebih tinggi dibandingkan wilayah yang kurang berkembang. Baik sebagai faktor penarik maupun sebagai pendorong.

Perkembangan wilayah akan memicu terjadinya urbanisasi adalah faktor penarik bagi bagi masyarakat, sedangkan berkembangnya wilayah yaitu aktivitas ekonomi yang 
menyebar akan memicu wilayah disekitarnya berkembang. Aktifitas-aktifitas ekonomi baru inilah yang menyebabkan permintaan lahan meningkat dan harga lahan juga naik. Selain itu kebutuhan terhadap tanah baik untuk industri, permukiman (properti) serta kebutuhan lain mengindikasikan bahwa investasi disuatu wilayah. Hal ini disebabkan oleh hampir semua kegiatan usaha riil memerlukan tanah. Semakin banyak permintaan akan tanah maka persaingan atas tanah menjadi lebih kuat. Bahkan lembaga yang melindungi tanah berperan bagi pertumbuhan ekonomi dan investasi karena tidak hanya mempengaruhi besarnya investasi tetapi juga input yang dialokasikan dalam usaha (Knack \& Keefer, 1995). Gambar 5 merupakan peta sebaran transaksi tanah, sedangkan Gambar hasil analisis interpolasi berdasarkan harga transaksi tanah di Kabupaten Cirebon (Gambar 6).

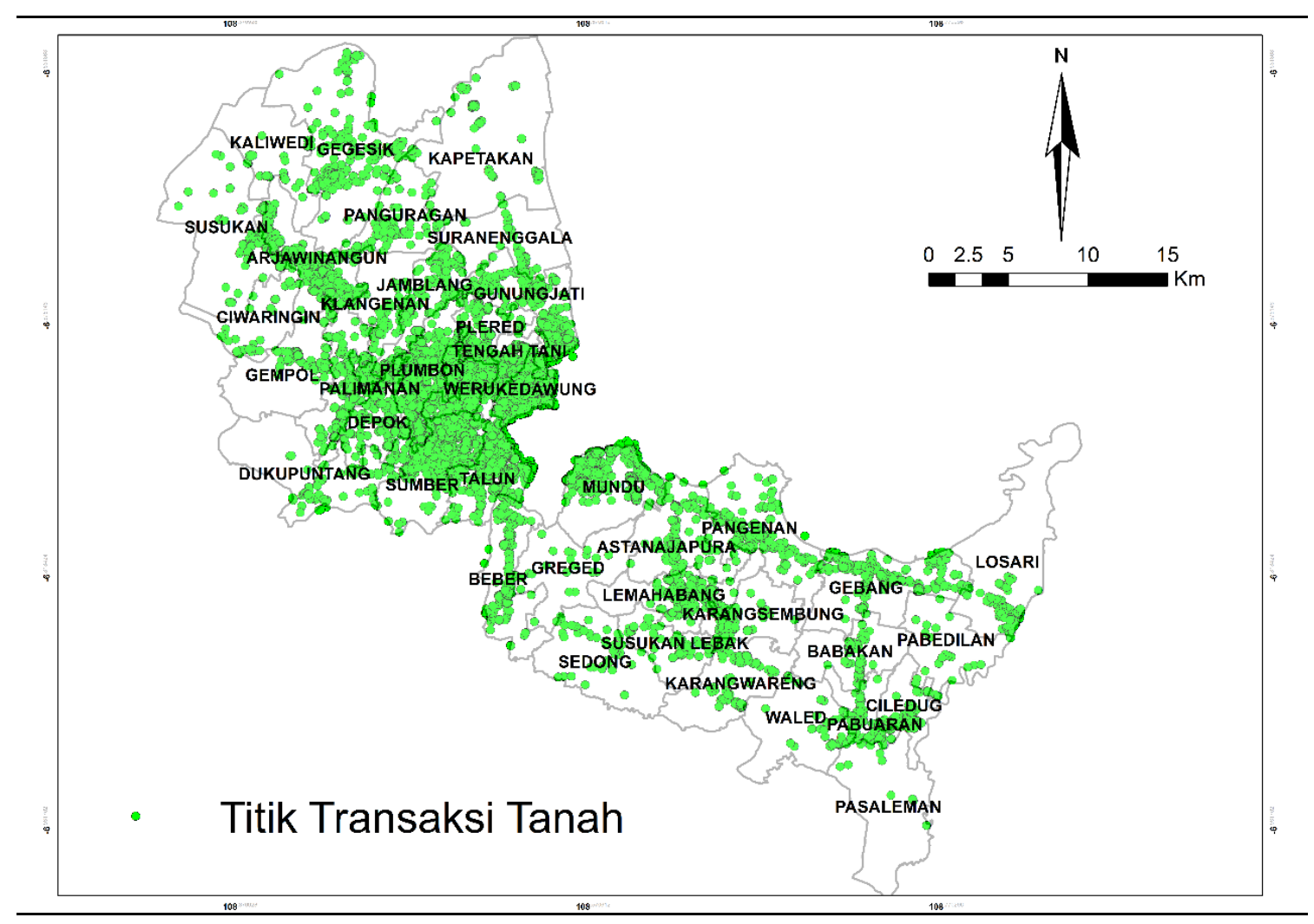

Gambar 5. Peta Sebaran Transaksi Tanah di Kabupaten Cirebon

Berdasarkan Gambar 5, transaksi berkumpul di beberapa wilayah seperti Kecamatan Palimanan, Depok, Weru, Plumbon dan Kedawung, Sumber dan Talun. Jika kita melihat dan membandingkan dengan peta pengembangan wilayah Gambar 2 dan Gambar 4, maka wilayah tersebut hampir semua termasuk kategori sangat berkembang. Selain itu disebagian wilayah Kecamatan Arjawinangun, Astanajapura, Lemahabang, serta Ciledug juga terlihat kumpulan titik-titik lokasi transaksi. Hal ini memperlihatkan bahwa di Wilayah ini terdapat jumlah transaksi tanah dan kebutuhan atas tanah lebih besar sehingga masuk dalam kategori berkembang. Wilayah kecamatan yang memiliki transaksi tanah relatif lebih sedikit juga merupakan wilayah yang kurang berkembang. Wilayah yang kurang berkembang juga memiliki kepadatan penduduk yang relatif lebih rendah dibandingkan wilayah yang berkembang dan sangat berkembang. Hal ini diduga mempengaruhi transaksi tanah di wilayah tersebut lebih rendah. 


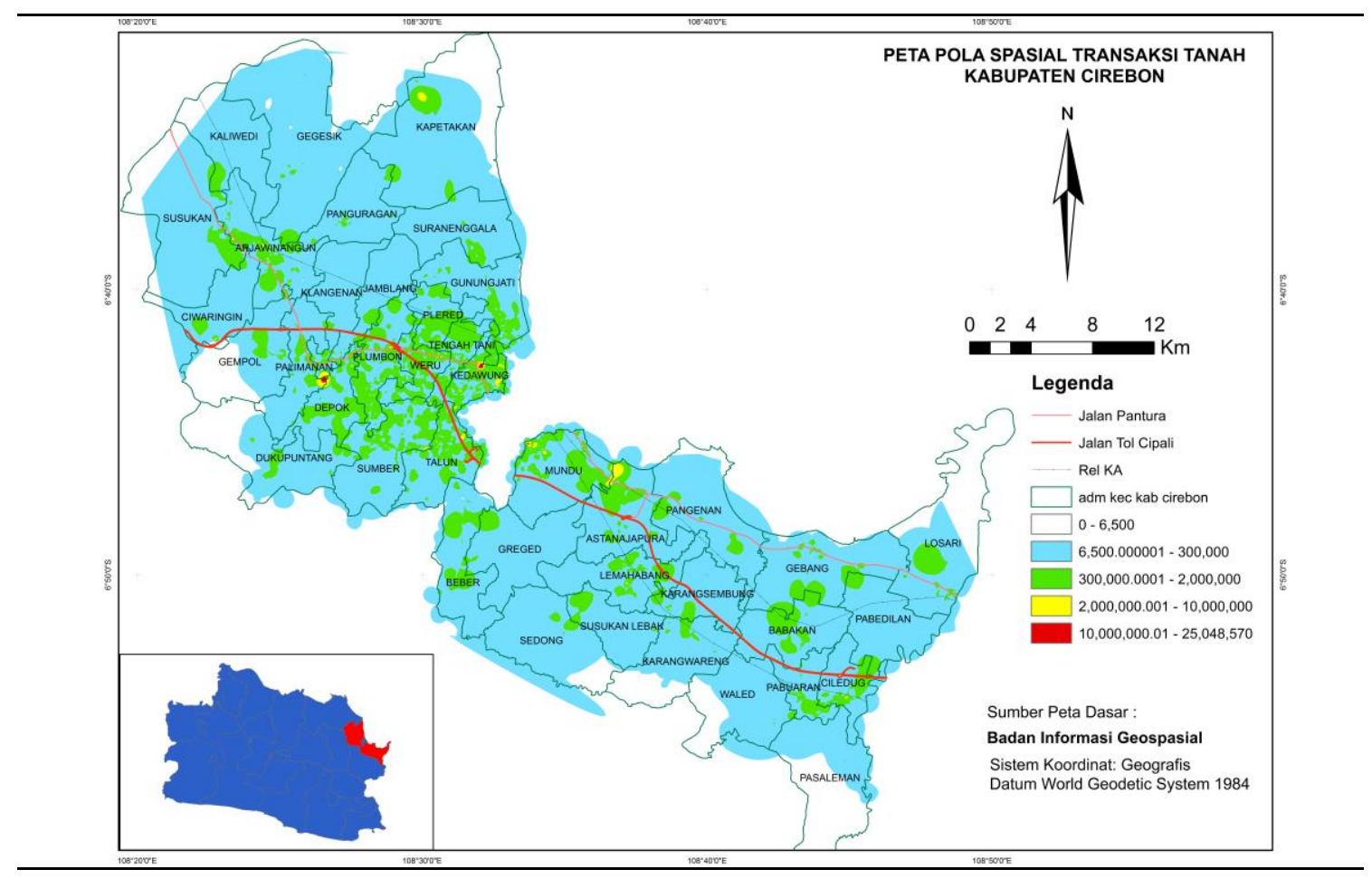

Gambar 6. Peta Pola Transaksi Tanah di Kabupaten Cirebon

Berdasarkan Gambar 6, diketahui bahwa wilayah yang sangat berkembang terlihat memiliki harga transaksi tanah yang lebih tinggi dibandingkan wilayah yang belum berkembang. Hal ini ditunjukan dengan rona warna merah untuk daerah Kecamatan Palimanan dan perbatasan Kecamatan Weru dan Kedawung. Daerah inilah mungkin menjadi indikator dan pemicu wilayah disekitarnya untuk berkembang. Sedangkan wilayah yang termasuk dalam kategori berkembang mempunyai harga yang moderat dibanding wilayah sangat berkembang dengan warna kuning dan hijau tua. Kemudian wilayah yang kurang berkembang bisa terlihat hampir sebagian besar wilayahnya berwarna hijau muda dengan rentang harga tanah Rp.6.500-Rp.300.000 per meter persegi, bahkan terlihat mempunyai warna putih. Warna putih pada Gambar 6, mengindikasikan bahwa transaksi jual beli tanah di wilayah tersebut atau dibawah harga Rp.6.500 atau tidak ada transaksi karena masuk dalam kawasan konservasi/hutan.

Hal ini sangat berkaitan dengan konsep kutub pertumbuhan (growth pole) Frans ois Perroux, bahwa pertumbuhan tidak muncul disembarang tempat yaitu di wilayah tertentu dengan intensitas dan penyebaran yang berbeda sehingga mempengaruhi beragam sektor ekonomi (Farizal et al., 2011) bahkan autokorelasi spasial dipusat-pusat pertumbuhan (Pratiwi \& Kuncoro, 2016).

Secara riil dilapangan, kedua wilayah tersebut adalah wilayah industri besar dan kawasan perdagangan dan jasa. Hal ini tidak bisa dihindari jika tanah dan sumber daya alam merupakan salah satu faktor yang mempengaruhi perkembangan wilayah. Sumber daya alam dapat menarik investor untuk mendirikan sejumlah industri seperti industri semen dan gas di wilayah Palimanan. Akan tetapi, perkembangan ekonomi suatu wilayah tidaklah berarti sangat bergantung pada tanah dan kekayaan alam. Beberapa wilayah justru dapat berkembang perekonomiannya bukan hanya dari kekayaan alam.

Kecamatan Kedawung yang berbatasan dengan Gunungjati dan Kota Cirebon memiliki rona pola transaksi berwarna merah, sama seperti di Kecamatan Palimanan. Jika dilihat secara langsung wilayah ini merupakan kawasan perdagangan dan jasa. Beberapa 
hotel, restoran, pusat perbelanjaan dan jasa keuangan berdiri di area tersebut. Hal ini mengindikasikan bahwa terdapat aktifitas perekonomian disana sehingga mempengaruhi nilai dan jumlah transaksi tanah. Selain itu Kecamatan Kedawung juga memiliki populasi penduduk yang sangat padat sehingga mendorong perkembangan wilayah. Senada dengan Dow, populasi yang lebih besar, ditempat yang lebih berkembang (Dow et al., 2017). Jika dilihat dari rasio tanah bersertifikat maka Kecamatan Kedawung memiliki rasio sertifikasi 95,3\% terhadap luas wilayah non kawasan hutan, dengan bahasa lain reformasi sertifikasi lahan meningkatkan kecenderungan bermigrasi untuk memperbaiki kondisi ekonomi. Menurut Löffler (1996) meningkatnya urbanisasi mempengaruhi hak atas tanah dan pasar tanah di daerah perkotaan dan pedesaan, meningkatkan likuiditas lahan dan mengurangi kendala keuangan (Chernina et.al, 2014).

Kecamatan Astanajapura berdasarkan Gambar 6 memperlihatkan warna kuning dibagian utara. Hal ini mengindikasikan bahwa terdapat transaksi tanah yang jumlah dan nilainya relatif lebih tinggi dibandingkan wilayah disekitarnya yang cenderung putih kehijauan. Transaksi tanah tinggi ini menunjukan adanya aktifitas ekonomi terkait dengan tanah. Secara spasial wilayah ini merupakan kawasan PLTU Cirebon (Cirebon Power) yang sempat terkendala persoalan lahan untuk ekspansi dan merupakan Proyek Strategis Nasional (PSN). Keberadaan industri ini diharapkan mampu menjadi pendorong terwujudnya poros metropolitan Cirebon Raya semakin terang. Selain persoalan lahan, ketersediaan listrik juga menjadi faktor utama dalam menarik investor (The World Bank, 2016).

Berdirinya PLTU Cirebon pada tahun 2012 dengan kapasitas 660MW menciptakan lapangan kerja baru baik dalam operasional dan maintenance. Pada tahun 2017 ekspansi PLTU Cirebon dengan kapasitas 1000MW dilakukan, tentunya akan memerlukan lahan baik untuk lokasi PLTU baru maupun permukiman dan fasilitas sosial dan umum disekitarnya untuk pekerja. Hal ini yang dapat mendorong terjadinya perubahan penggunaan lahan. Selain faktor bio-fisik secara tidak langsung, sosial ekonomi menjadi faktor utama terjadinya perubahan penggunaan lahan (Yudarwati et al., 2017) umumnya berubah dari lahan pertanian menjadi non pertanian (Setiowati \& Sudirman, 2015). Menurut Hidayati \& Kinseng (2013) Pola konversi lahan pertanian terjadi secara cepat dengan penggantian penguasaan lahan ke pihak lahan, sehingga berpindahnya kepemilikan lahan (transaksi tanah) menyebabkan inkonsistensi pola ruang (Dani et al., 2017).

\section{KESIMPULAN}

Tingkat perkembangan wilayah di Kabupaten Cirebon berdasarkan indeks entropi wilayah diklasifikasikan menjadi tiga yaitu sangat berkembang yang terdiri dari Kecamatan Palimanan, Depok, Weru, Plumbon dan Plered. Kecamatan Palimanan memiliki indeks entropi terbesar yaitu 0,2931. Klasifikasi berkembang antara lain Kecamatan Arjawinangun, Susukan, Kapetakan, Gegesik, Panguragan, Gunungjati, Tengah Tani, Kedawung, Sumber, Talun, Dukupuntang, Mundu, Astanajapura, Lemah Abang, Gebang, Ciledug serta klasifikasi kurang berkembang ada di kecamatan-kecamatan lain dengan indeks entropi paling rendah 0,0641 di Kecamatan Pasaleman.

Pola sebaran transaksi tanah di Kabupaten Cirebon adalah mengumpul di wilayah yang sangat berkembang dan berkembang, kemudian berdasarkan hasil analisis interpolasi natural neighbor terdapat dua titik wilayah yang sangat tinggi jumlah dan nilai transaksinya yaitu di Kecamatan Palimanan dan Perbatasan Kedawung dengan Kota Cirebon. Dua wilayah ini yang diduga menjadi pusat perkembangan wilayah sehingga wilayah disekitarnya menjadi sangat berkembang. Wilayah yang sangat berkembang cenderung memiliki jumlah dan nilai transaksi tanah lebih besar dibandingkan wilayah belum berkembang. 


\section{DAFTAR PUSTAKA}

Badan Pusat Statistik. (2016). Kabupaten Cirebon dalam Angka 2016. Cirebon.

Chernina, E., Castañeda Dower, P., \& Markevich, A. (2014). Property rights, land liquidity, and internal migration. Journal of Development Economics, 110, 191-215. https://doi.org/10.1016/j.jdeveco.2013.03.010

Dani, E. T., Sitorus, S. R. P., \& Munibah, K. (2017). ANALISIS PENGGUNAAN LAHAN DAN ARAHAN PENGENDALIAN PEMANFAATAN RUANG DI KABUPATEN BOGOR. Tataloka, 19(1), 40-52. https://doi.org/10.14710/tataloka.19.1.40-52

Dow, G. K., Mitchell, L., \& Reed, C. G. (2017). The economics of early warfare over land. Journal of Development Economics, 127, 297-305. https://doi.org/10.1016/j.jdeveco.2017.04.002

Farizal, F., Hidayanti, A. N., \& Kumcoro, T. (2011). Penentuan Faktor-Faktor Yang Mempengaruhi Terbentuknya Pusat Pertumbuhan ( Studi Kasus : Kabupaten Bima , Nusa Tenggara Barat ). Jurnal Tata Kota Dan Daerah, 3(1), 39-46.

Hidayati, H. N., \& Kinseng, R. A. (2013). KONVERSI LAHAN PERTANIAN DAN SIKAP PETANI DI DESA CIHIDEUNG ILIR KABUPATEN BOGOR. Jurnal Sosiologi Pedesaan, 259-268.

Istikomah. (2013). Pengaruh program sertifikasi tanah terhadap akses permodalan bagi usaha mikro dan kecil. Kawistara, 3(1), 24-40.

Johnson, S., McMillan, J., \& Woodruf, C. (2002). American Economic Association. The Journal of Economic Perspectives, 92(5), 1335-1356. https://doi.org/10.1257/000282802762024539

Knack, S., \& Keefer, P. (1995). Institutions and Economic Performance: Cross-Country Tests Using Alternative Institutional Measures. Economics \& Politics, 73), 207-227. https://doi.org/10.1111/j.14680343.1995.tb00111.x

Löffler, U. (1996). Land Tenure Developments in Indonesia. Retrieved from http://www.mekonginfo.org/assets/midocs/0001794-planning-cadastre-land-tenure-developments-inindonesia.pdf

Munibah, K., Sitorus, S. R. P., Rustiadi, E., Gandasasmita, K., \& Hartrisari. (2009). Model Hubungan antara Jumlah Pendudukan dengan Luas Lahan Pertanian dan Permukiman (Studi Kasus DAS Cidanau, Provinsi Banten). Jurnal Tanah Dan Lingkungan, 11(1), 32-40.

Panuju, D. R., \& Rustiadi, E. (2012). Teknik Analisis Perencanaan Pengembangan Wilayah. Bogor: IPB.

Pramono, G. H. (2008). Akurasi Metode IDW dan Kriging untuk Interpolasi Sebaran Sedimen Tersuspensi. In Forum Geografi (Vol. 22, pp. 97-110).

Pratiwi, M. C. Y., \& Kuncoro, M. (2016). Analisis Pusat Pertumbuhan dan Autokorelasi Spasial di Kalimantan: Studi Empiris di 55 Kabupaten/Kota, 2000-2012. Jurnal Ekonomi Dan Pembangunan Indonesia, 16(2), 81-104.

Reerink, G., \& van Gelder, J. L. (2010). Land titling, perceived tenure security, and housing consolidation in the kampongs of Bandung, Indonesia. Habitat International, 34(1), $78-85$. https://doi.org/10.1016/j.habitatint.2009.07.002

Rustiadi, E., Pribadi, D. O., Panuju, D. R., \& Pravitasari, A. E. (2017). Permodelan Perencanaan dan Pengembangan Wilayah. Jakarta: Crestpent Press dan Yayasan Obor Indonesia.

Rustiadi, E., Saefulhakim, S., \& Panuju, D. R. (2009). Perencanaan dan Pengembangan Wilayah. Jakarta: Crestpent Press dan Yayasan Obor Indonesia.

Setiowati, \& Sudirman, S. (2015). Perubahan Penggunaan Lahan Pertanian Menjadi Non Pertanian dan Faktor Penyebabnya di Kabupaten Magelang. Bhumi, 1(2), 198-214.

Sitorus, S. R. P., Leonataris, C., \& Dyah, R. P. (2012). ANALISIS POLA PERUBAHAN PENGGUNAAN LAHAN DAN PERKEMBANGAN WILAYAH DI KOTA BEKASI, PROVINSI JAWA BARAT, 14(1), 21-28.

The World Bank. (2016). Doing Business 2016: Measuring Regulatory Quality and Efficiency. https://doi.org/10.1596/978-1-4648-0667-4

The World Bank. (2017). Doing Business 2017: Equal Opportunity for All. https://doi.org/10.1596/978-14648-0948-4

Wei, S. J., Zhang, X., \& Liu, Y. (2017). Home ownership as status competition: Some theory and evidence. Journal of Development Economics, 127, 169-186. https://doi.org/10.1016/j.jdeveco.2016.12.001

Williamson, C. R. (2010). The Two Sides of de Soto: Property Rights, Land Titling, and Development. In C. Emily \& J. Kodl (Eds.), The Annual Proceedings of The Wealth and Well-Being of Nations 2009-2010 (Vol. 88, pp. 95-108). 
Winarso, H., \& Firman, T. (2002). Residential land development in Jabotabek, Indonesia: Triggering economic crisis? Habitat International, 26(4), 487-506. https://doi.org/10.1016/S0197-3975(02)00023-1

Yudarwati, R., Sitorus, S. R. P., \& Munibah, K. (2017). Arahan Pengendalian Perubahan Penggunaan Lahan Menggunakan Markov - Cellular Automata Di Kabupaten Cianjur. Tataloka, 18(4), 211. https://doi.org/10.14710/tataloka.18.4.211-221 